\title{
Pengaruh Kualitas Website, Impulsive Personality Trait, Dan Kelompok Referensi Terhadap Pembelian Impulsif di Tokopedia
}

\author{
Reza Adian Putri*1, Yessy Artanti ${ }^{2}$ \\ ${ }^{1,2}$ Fakultas Ekonomika dan Bisnis Universitas Negeri Surabaya \\ Jl. Ketintang, Ketintang, Kec. Gayungan, Kota SBY, Jawa Timur 60231, Indonesia \\ *reza.17080574004@mhs.unesa.ac.id
}

\begin{abstract}
The development of the online market is currently able to shift people's shopping tastes from conventional to digital, this is confirmed by the emergence of various e-commerce that compete with each other in Indonesia and are able to change people's behavior to be more impulsive. The purpose of this study was to determine whether website quality, impulsive personality trait, and reference groups have a positive influence on impulsive purchases among Tokopedia.com e-commerce users. This research is an explanatory research type with research variables consisting of independent variables, namely website quality, impulsive personality trait, and reference groups as well as the dependent variable, namely impulsive buying. The sampling technique used in this research is non probability with judgemental sampling. Data collection is through questionnaires. Methods of data analysis using multiple linear regression analysis. The result showed that the variable website quality, impulsive personality trait and reference groups had a positive and significant effect on the variable impulsive buying of e-commerce Tokopedia.com users.
\end{abstract}

Keywords : Website Quality; Impulsive Personality Trait; Reference Group; Impulse Buying.

Abstrak

Berkembangnya pasar online saat ini mampu menggeser selera belanja masyarakat dari konvensional menjadi digital, hal tersebut dipertegas dengan munculnya berbagai e-commerce yang saling bersaing di Indonesia dan mampu mengubah perilaku masyarakat menjadi lebih impulsif. Tujuan penelitian ini adalah untuk menentukan apakah kualitas website, impulsive personality trait, dan kelompok referensi mempunyai pengaruh positif terhadap pembelian impulsif pada e-commerce Tokopedia.com. Penelitian ini termasuk jenis penelitian explanatory dengan variabel penelitian yang terdiri atas variabel independen yaitu kualitas website (X1), impulsive personality trait (X2), dan kelompok referensi (X3) serta variabel dependen yaitu pembelian impulsif (Y). Teknik pengambilan sampling pada penelitian ini adalah nonprobability dengan metode judgemental sampling. Pengumpulan data melalui kuesioner dengan metode analisis data menggunakan analisis regresi linear berganda. Hasil penelitian menunjukkan bahwa variabel kualitas website, impulsive personality trait, dan kelompok referensi secara bersama-sama berpengaruh positif dan signifikan terhadap variabel pembelian impulsif pada pengguna e-commerce Tokopedia.com.

Kata Kunci - Kualitas Website; Impulsive Personality Trait; Kelompok Referensi; Pembelian Impulsif.

\section{PENDAHULUAN}

Perkembangan teknologi terbilang mengalami kemajuan yang pesat secara global maupun di Indonesia. Hal tersebut mampu dipertegas dengan semakin berkembangnya pasar online yang mampu menggeser selera berbelanja masyarakat dari konvensional menjadi digital ekonomi atau $e$ commerce. Sebanyak 54\% responden di Asia Tenggara akan melakukan pembelian secara online apabila mereka sedang membutuhkan atau menginginkannya. Indonesia berada pada peringkat pertama sebagai negara dengan pertumbuhan e-commerce tercepat di dunia sebanyak $78 \%$ [1]. Belanja online merupakan proses transaksi menggunakan media sosial atau jejaring sosial yang menyediakan barang atau jasa untuk diperjualbelikan. Berbelanja secara online berkembang baik dari segi pelayanan, efektifitas, keamanan dan popularitas saat ini [2].
Roy Mandey, Ketua Umum Asosiasi Pengusaha Ritel Indonesia (APRINDO), menyampaikan bahwa masyarakat saat ini telah mengalami perubahan perilaku, terutama dalam pola belanja. Belanja online dapat meminimalisir tenaga dan waktu yang dikeluarkan konsumen, karena hanya dengan mengunjungi website maka konsumen dapat melakukan transaksi pembelian. Kemudahan transaksi dalam berbelanja ternyata mempengaruhi perilaku masyarakat, yakni cenderung menjadi lebih konsumtif, sering melakukan pembelian tanpa perencanaan, secara spontan dan kurang mempertimbangkan konsekuensi [3]. Pola belanja masyarakat menjadi lebih modern dengan lebih mementingkan kesenangan, gaya hidup dan kenikmatan belanja yang dapat mengarahkan masyarakat sering melakukan pembelian tidak terencana atau yang disebut sebagai pembelian impulsif, dimana konsumen tidak menentukan merek maupun kategori produk yang akan dibeli sebelumnya 
[4]. Pembelian impulsif dapat terjadi kapan saja termasuk pada saat mengunjungi situs belanja online pada e-commerce tertentu. Beberapa indikator pembelian impulsif yakni membeli barang diluar daftar belanja, membeli produk yang bukan bermaksud untuk dibeli, kelompok orang yang membuat pembelian tidak terencana, membeli tanpa mempedulikan akibat, dan menyukai pembelian spontan [5].

Sebuah perusahaan retail online diharuskan mampu menghadirkan website dengan kualitas yang baik, karena hal ini merupakan salah satu faktor yang dapat mempengaruhi konsumen dalam memutuskan pembelian. Website merupakan gudang utama yang dicari konsumen karena dapat membantu dalam mencari informasi [6]. Kualitas website memiliki lima dimensi yaitu ease of use, reliability, accessibility, visual appeal, dan website appearance dengan pengaruh yang positif terhadap pembelian impulsif [7].

Faktor lain yang dapat memicu pembelian impulsif adalah kepribadian konsumen. Konsumen memiliki berbagai macam karakteristik dan sifat yang berbeda-beda, begitupun dengan cara mereka dalam melakukan pembelian. Perilaku konsumen dipengaruhi dengan bagaimana sifat yang melekat pada dirinya [8]. Impulsive personality trait merupakan aspek kepribadian yang memungkinkan seseorang melakukan pembelian karena dorongan yang kuat dari dalam diri. Impulsive personality trait seringkali diukur dengan indikator membeli spontan, membeli sesuai perasaan saat itu, merencanakan pembelian dengan cermat, saat melihat langsung membeli, ceroboh, tanpa berpikir, mendadak, dan berpikir nanti [9].

Terkait dengan situs belanja online pada $e$ commerce, keputusan pembelian yang bersifat impulsif dapat dipicu oleh dorongan orang-orang sekitar dengan memberikan ulasan baik. Kelompok referensi terdiri dari individu atau kelompok yang melakukan interaksi hingga dapat mempengaruhi perilaku konsumen tersebut ketika melakukan pembelian suatu produk [10]. Apabila individu merasa nyaman pada lingkunganya, maka akan meningkatkan kecenderungan pembelian secara impulsif. Kelompok referensi dapat diukur dengan indikator pengetahuan, kredibilitas, pengalaman, keaktifan, dan daya tarik [11].

Beberapa $e$-commerce yang berkembang pesat di Indonesia adalah jenis marketplace seperti Tokopedia.com, Shopee.co.id, Lazada.com dan Blibli.com. Kemudahan akses berbelanja online memudahkan masyarakat untuk memenuhi kebutuhan sehari-hari. Tokopedia.com merupakan e-commerce pelopor transformasi digital di dalam negeri yang berdiri pada tahun 2009 oleh William Tanuwijaya dan Leontinus Alpha Edison, dan pada tahun yang sama Tokopedia.com meraih penghargaan sebagai $e$ commerce terbaik [12]. Meskipun Tokopedia.com telah menyediakan berbagai fasilitas yang dibutuhkan konsumen, mereka seringkali tetap mencari pilihan $e$ commerce lain untuk dijadikan alternatif. Namun dalam pelaksanaannya masih banyak kekurangankekurangan yang dirasakan pengunjung Tokopedia.com seperti website yang sering dilakukan maintenance dengan waktu yang cukup lama [13].

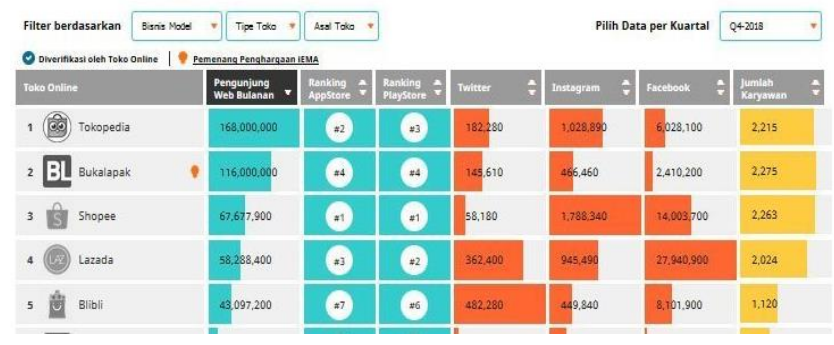

Sumber: Iprice.com [14]

Gambar 1. Top E-Commerce Tahun 2018

Berdasarkan data pada gambar 1, Tokopedia.com pada kuartal 1 hingga kuartal 4 tahun 2018 berada di posisi puncak dengan jumlah kunjungan sebanyak 168 juta pengunjung per bulan dengan jumlah karyawan sebanyak 2.215 orang. Selanjutnya peringkat kedua ditempati oleh Bukalapak.com dan ketiga ditempati oleh Shopee.co.id.

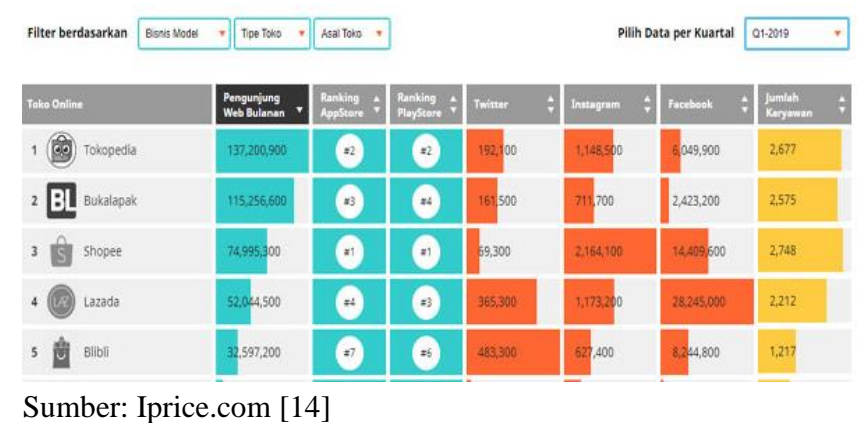

Gambar 2. Top E-Commerce Tahun 2019

Pada tahun 2019 di kuartal 1 hingga kuartal 3 Tokopedia.com tetap menjadi e-commerce nomor satu di Indonesia dengan jumlah kunjungan sekitar 137 juta pengunjung per bulan dengan peningkatan jumlah karyawan sebanyak 2.677 orang. Bukalapak.com tetap berada di posisi kedua dan shopee.co.id berada di posisi ketiga. 


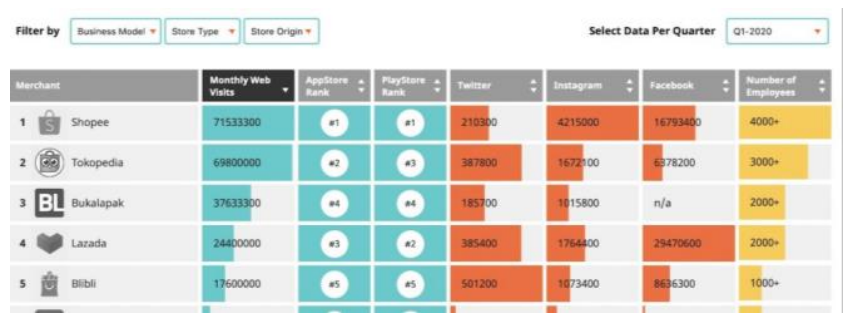

Sumber: Iprice.com [14]

Gambar 3. Top E-Commerce Tahun 2020

Dimulai pada kuartal 4 tahun 2019 hingga kuartal 3 tahun 2020, Shopee.co.id mampu menggeser posisi Tokopedia.com seagai e-commerce teratas dengan kunjungan belanja sekitar 71,5 juta pengunjung dengan jumlah karyawan sekitar 4000 orang. Sedangkan Tokopedia.com mengalami penurunan drastis, dengan kunjungan belanja sekitar 69,8 juta pengunjung dengan jumlah karyawan 3000 orang.

Tokopedia.com merupakan salah satu ecommerce di Indonesia yang selalu menduduki posisi puncak peringkat e-commerce terbaik setiap tahun, namun pada tahun 2020 mampu dikalahkan oleh ecommerce shopee.co.id. berdasarkan fenomena tersebut maka penelitian ini bertujuan untuk mengetahui pengaruh antara kualitas website, impulsive personality trait dan kelompok referensi terhadap pembelian impulsif pada pengunjung ecommerce Tokopedia.com.

\section{Pembelian Impulsif}

\section{KAJIAN PUSTAKA}

Pembelian impulsif atau Impulse buying merupakan pembelian yang dapat terjadi pada saat konsumen mengunjungi outlet secara langsung maupun saat berbelanja secara online. Pembelian impulsif didefinisikan sebagai suatu tindakan yang tidak direncanakan, dan membeli secara spontan tanpa mempertimbangkan konsekuensi [3]. Pembelian impulsif seringkali dikaitkan dengan pengambilan keputusan yang relatif lebih cepat dan instan tanpa memerlukan waktu yang lama untuk berpikir [15]. Sesuai dengan istilahnya, pembelian impulsif ini tidak direncanakan sebelumnya, yaitu konsumen tidak menentukan produk atau jasa apa yang akan digunakan. Pembelian impulsif dapat terjadi apabila muncul keinginan yang kuat secara tiba-tiba akibat adanya faktor-faktor yang diciptakan oleh pemasar.

\section{Kualitas Website}

Kualitas website merupakan salah satu konsep dalam mengukur kualitas pelayanan yang bergantung pada persepsi pengguna akhir. Desain sebuah website harus dibuat semenarik mungkin dan mudah untuk dioperasikan karena hal tersebut dapat menimbulkan pengalaman yang positif kepada konsumen yang pada akhirnya akan mendorong konsumen untuk berbelanja pada website tersebut [16]. Kualitas website merupakan salah satu faktor utama dalam pemasaran online karena dapat mempengaruhi loyalitas konsumen. Kualitas website terdiri dari beragam konten yang disusun sedemikian rupa sehingga memudahkan konsumen dalam mengoperasikan dan memanfaatkan website tersebut.

\section{Impulsive Personality Trait}

Impulsive personality trait merupakan aspek kepribadian yang memungkinkan seseorang untuk melakukan gerakan cepat tanpa berpikir dalam memutuskan atau mempertimbangkan alternatif pilihan dalam melakukan pembelian [17]. Kepribadian terdiri dari beberapa karakteristik fisik dan psikologis individu yang berdampak pada sebuah tindakan atau sikap. Impulsive personality trait merupakan kecenderungan sifat individu untuk melakukan pembelian berdasarkan godaan dan dorongan yang ditanggapi secara positif dan cepat [18]. Sifat impulsif pada setiap individu akan berbeda dengan individu lainnya. Perbedaan kepribadian individu mampu menimbulkan berbagai macam pengalaman saat melakukan pembelian. Kurangnya kontrol diri konsumen menandakan ketidakmampuannya untuk menunda kepuasan, sehingga mengarahkan pada pembelian impulsif. Impulsive personality trait memungkinkan seseorang untuk melakukan pembelian tanpa berpikir karena adanya dorongan dari dalam diri sehingga tidak dapat memutuskan atau mempertimbangkan alternatif pilihan yang lebih baik saat melakukan pembelian.

\section{Kelompok Referensi}

Kelompok acuan (reference group) merupakan satu atau kumpulan beberapa orang yang saling mempengaruhi dalam perilaku pembelian. Kelompok referensi sering dijadikan dasar pembanding konsumen dalam membentuk respon afektif maupun kognitif saat melakukan pembelian berdasarkan pengalaman. Secara tidak langsung kelompok referensi menjadi standar dan nilai yang berpengaruh terhadap perilaku seseorang [10]. Kelompok referensi berasal dari kelompok sosial yang berinteraksi secara 
terus menerus hingga menjadi ukuran seseorang untuk membentuk perilakunya [19]. Kelompok referensi dapat memberikan standar terhadap perilaku seseorang dalam melakukan pembelian. Referensi bagi seseorang bisa berasal dari kelas dan budaya bahkan subbudaya yang sama atau berbeda.

\section{Kualitas Website dengan Pembelian Impulsif}

Menurut hasil penelitian dari beberapa ahli menyatakan bahwa pembeli secara online memiliki peran ganda yaitu sebagai konsumen dan pengguna website, maka dibutuhkan website yang berkualitas untuk memudahkan konsumen dalam menemukan produk yang dicari, sehingga dalam penelitian tersebut dikatakan kualitas website memiliki pengaruh positif dan signifikan terhadap pembelian impulsif [6], [20], [21]. Website yang telah terverifikasi KEMENKOMINFO lebih meningkatkan pembelian impulsif secara signifikan [21]. Namun, hasil berbeda ditemukan dalam penelitian para ahli yang menyatakan bahwa tidak terdapat pengaruh yang signifikan antara kualitas website dengan pembelian secara impulsif. Dalam penelitian tersebut ditemukan kualitas website tidak dapat berdiri sendiri untuk membentuk pembelian secara impulsif, namun memerlukan beberapa faktor pendorong lain seperti promosi penjualan [22]. Dari kajian teori tersebut terjadi inkonsistensi sehingga terdapat peluang untuk meneliti tentang kualitas website terhadap pembelian impulsif.

\section{Impulsive Personality Trait dengan Pembelian Impulsif}

Sifat kepribadian lebih penting dalam menentukan kecenderungan impulsivitas daripada pendapatan dan jenis kelamin, karena sifat impulsif sudah tertanam dalam kepribadian yang melekat pada individu sehingga impulsive personality trait memiliki pengaruh positif dan signifikan terhadap pembelian impulsif [9]. Hal tersebut sejalan dengan hasil penelitian beberapa ahli bahwa impulsive personality trait memiliki pengaruh positif dan signifikan terhadap perilaku pembelian impulsif [18], [20]. Namun, terdapat hasil penelitian berbeda yang menyatakan bahwa impulsive personality trait tidak cukup kuat dalam mempengaruhi seseorang untuk melakukan pembelian impulsif jika tidak didorong oleh faktor eksternal seperti lingkungan toko, sehingga impulsive personality trait dikatakan tidak memiliki pengaruh signifikan terhadap pembelian impulsif [23]. Dari kajian teori tersebut terjadi inkonsistensi sehingga terdapat peluang untuk meneliti tentang impulsive personality trait terhadap pembelian impulsif.

\section{Kelompok Referensi dengan Pembelian Impulsif}

Kelompok referensi yang diukur dengan indikator pengetahuan, kredibilitas, pengalaman, keaktifan, dan daya tarik, menyatakan bahwa kelompok referensi dapat digunakan pengguna e-commerce sebagai acuan untuk meningkatkan keyakinan dan memberikan gambaran sebelum memutuskan pembelian pada situs belanja online, maka dalam penelitian tersebut dikatakan bahwa kelompok referensi berpengaruh positif dan signifikan terhadap pembelian impulsif [11]. Hal tersebut sejalan dengan hasil penelitian beberapa ahli bahwa kelompok referensi berpengaruh signifikan positif terhadap pembelian impulsif, yang berarti semakin besar tekanan kelompok referensi yang diterima konsumen maka akan semakin tinggi kecenderungan konsumen melakukan pembelian impulsif [24], [25].

Sedangkan hasil berbeda didapatkan oleh para ahli yang menyatakan kelompok referensi tidak memiliki pengaruh signifikan terhadap pembelian impulsif karena meskipun kelompok referensi mempengaruhi secara langsung, namun dalam melakukan pembelian impulsif terdapat faktor-faktor lain yang mempengaruhi, salah satunya adalah karakteristik konsumen. Konsumen kerap menerima opini dan informasi dari orang lain namun tetap akan dipertimbangkan kembali [26]. Dari kajian teori tersebut terjadi inkonsistensi sehingga terdapat peluang untuk eneliti tentang kelompok referensi terhadap pembelian impulsif.

Hipotesis

Berdasarkan uraian pengaruh antar variabel diatas, maka hipotesis dalam penelitian ini sebagai berikut:

$\mathrm{H} 1$ : Kualitas website berpengaruh signifikan terhadap pembelian impulsif pada e-commerce Tokopedia.com.

$\mathrm{H} 2$ : Impulsive personality trait berpengaruh signifikan terhadap pembelian impulsif pada $e$ commerce Tokopedia.com.

H3: Kelompok referensi berpengaruh signifikan terhadap pembelian impulsif pada e-commerce Tokopedia.com. 
III. METODE PENELITIAN

Model yang digunakan dalam penelitian ini sebagai berikut:

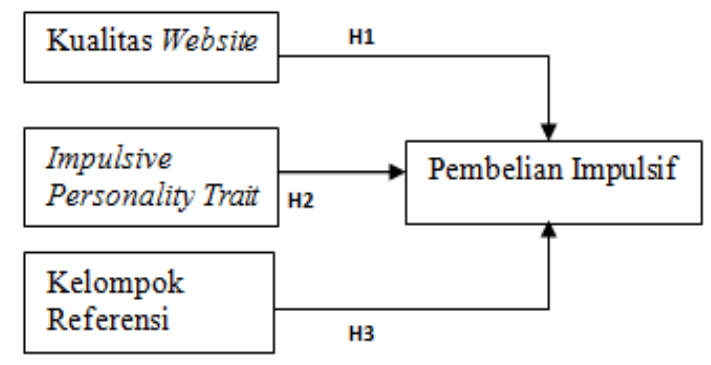

Sumber: diolah peneliti

Gambar 4. Kerangka Model Penelitian

Penelitian ini merupakan penelitian konklusif dengan menguji hipotesis dan hubungan secara spesifik yang dianalisis secara kuantitatif [27]. Penelitian ini menggunakan populasi bersifat infinite yang berarti jumlah populasi yang diteliti tidak diketahui yaitu seluruh pengguna e-commerce Tokopedia.com. Penelitian ini merupakan hasil jawaban yang dikumpulkan melalui studi lapangan dengan melakukan penyebaran angket online melalui sosial media instagram dan whatsapp.

Teknik sampling yang digunakan adalah nonprobability dengan metode judgemental sampling. Responden penelitian ini berusia 18-39 tahun dan pernah melakukan pembelian secara impulsif di Tokopedia.com. Responden yang dibutuhkan sebesar 30 responden untuk uji validitas dan reliabilitas serta 200 responden untuk pengujian hipotesis. Pengukuran penelitian ini menggunakan skala likert dengan rentang 1 (sangat tidak setuju) sampai 5 (sangat setuju). Metode analisis data yang digunakan adalah regresi linear berganda.

Pengukuran masing-masing variabel sebagai berikut: pengukuran variabel kualitas website peneliti mengembangkan dari indikator penelitian para ahli yang terdiri dari 6 indikator yaitu ease of use (kemudahan), reliability (reliabilitas), accessibility (aksesibilitas), visual appeal (daya tarik visual), appearance (tampilan website), service interaction (interaksi layanan) [7].

Untuk mengukur variabel impulsive personality trait menggunakan 5 indikator yaitu membeli barang sesuai dengan perasaan saat itu, saat melihat ingin membeli, kurang cermat saat melakukan pembelian, harus melakukan pembelian saat itu juga, merasa ingin membeli sesuatu secara tiba-tiba [28], [23].
Selanjutnya, pengukuran variabel kelompok referensi terdiri 5 indikator yaitu pengetahuan, pengalaman, kredibilitas, keaktifan, dan daya tarik [29], [30]. Sedangkan pengukuran variabel pembelian impulsif menggunakan indikator yang terdiri dari 4 indikator yaitu membeli sesuatu yang tidak direncanakan, membeli di luar daftar belanja, belanja tanpa mempedulikan akibat, dan membeli tanpa pikir panjang [6], [31].

\section{HASIL DAN PEMBAHASAN}

Hasil Uji Validitas dan Reliabilitas

Uji validitas dalam penelitian ini dilakukan pada 30 responden di luar dari 200 responden penelitian ini. Hasil uji validitas dapat dilihat pada tabel 1 .

\begin{tabular}{|c|c|c|c|}
\hline Item & r hitung & $r$ tabel & Ket. \\
\hline \multicolumn{3}{|c|}{ Kualitas Website (X1) } & \\
\hline $\mathrm{X} 1.1$ & 0,547 & & Valid \\
\hline $\mathrm{X} 1.2$ & 0,452 & & Valid \\
\hline $\mathrm{X} 1.3$ & 0,574 & & Valid \\
\hline $\mathrm{X} 1.4$ & 0,840 & & Valid \\
\hline $\mathrm{X} 1.5$ & 0,683 & & Valid \\
\hline $\mathrm{X} 1.6$ & 0,719 & & Valid \\
\hline \multicolumn{4}{|c|}{ Impulsive Personality Trait (X2) } \\
\hline $\mathrm{X} 2.1$ & 0,712 & \multirow{5}{*}{0,3610} & Valid \\
\hline $\mathrm{X} 2.2$ & 0,768 & & Valid \\
\hline $\mathrm{X} 2.3$ & 0,831 & & Valid \\
\hline $\mathrm{X} 2.4$ & 0,798 & & Valid \\
\hline $\mathrm{X} 2.5$ & 0,669 & & Valid \\
\hline \multicolumn{4}{|c|}{ Kelompok Referensi (X3) } \\
\hline $\mathrm{X} 3.1$ & 0,821 & \multirow{5}{*}{0,3610} & Valid \\
\hline $\mathrm{X} 3.2$ & 0,654 & & Valid \\
\hline $\mathrm{X} 3.3$ & 0,634 & & Valid \\
\hline X3.4 & 0,858 & & Valid \\
\hline $\mathrm{X} 3.5$ & 0,884 & & Valid \\
\hline \multicolumn{4}{|c|}{ Pembelian Impulsif (Y) } \\
\hline Y.1 & 0,767 & \multirow{4}{*}{0,3610} & Valid \\
\hline Y.2 & 0,878 & & Valid \\
\hline Y.3 & 0,702 & & Valid \\
\hline Y.4 & 0,899 & & Valid \\
\hline
\end{tabular}

Sumber: Output SPSS 22

Berdasarkan data pada tabel 1 , diperoleh hasil nilai $r$ hitung dari semua item pernyataan menunjukkan lebih besar dari $r$ tabel sehingga semua item pernyataan kuesioner tersebut dinyatakan valid.

Uji reliabilitas dalam penelitian ini dilakukan kepada 30 responden yang sama dengan uji validitas. Reliabilitas suatu konstruk variabel dapat dikatakan baik atau dianggap reliabel jika nilai Cronbach's Alpha $>0,6[32]$. 
Tabel 2. Hasil Analisis Uji Reliabilitas

\begin{tabular}{ccc}
\hline & Cronbach's Alpha & N of items \\
\hline X.1 &, 767 & 6 \\
X.2 &, 878 & 5 \\
X.3 &, 702 & 5 \\
Y.1 &, 899 & 4 \\
Sumber: Output SPSS 22
\end{tabular}

Berdasarkan hasil analisis tabel 2, nilai cronbach's Alpha seluruh variabel lebih besar dari 0,6 sehingga disimpulkan bahwa seluruh item pernyataan dalam penelitian ini dinyatakan reliabel.

\section{Karakteristik Responden}

Responden dari penelitian ini adalah seluruh pengguna Tokopedia.com yang memiliki rentang usia 18-39 tahun dan pernah melakukan pembelian secara impulsif pada Tokopedia.com. Hasil pengolahan data kuesioner menunjukan bahwa karakteristik mayoritas responden adalah perempuan $(67,5 \%)$ berusia $18-25$ tahun (96\%) dan 25-39 tahun (4\%). Pendidikan terakhir yang ditempuh responden mayoritas SMA/sederajat $(91,5 \%)$ dengan penghasilan $<\mathrm{Rp}$ $1.000 .000(53 \%)$.

\section{Hasil Uji Asumsi Klasik}

Model regresi linier berganda dapat dikatakan baik dan sesuai jika model tersebut memenuhi asumsi normalitas data dan terbatas dari asumsi-asumsi klasik statistik yaitu multikolinearitas dan heteroskedastisitas.

Uji normalitas bertujuan untuk menguji variabel pengganggu atau residual memiliki distribusi normal atau tidak. Apabila nilai signifikan yang dihasilkan > 0,05 maka distribusi dapat dikatakan normal. Uji normalitas pada penelitian ini menggunakan uji one sample kolmogorov smirnov dengan hasil signifikansi lebih besar dari 0,05 yakni sebesar 0,68. Maka dapat disimpulkan bahwa residual berdistribusi normal.

Berikutnya dilakukan Uji multikolinearitas yang bertujuan untuk menguji apakah model regresi terdapat korelasi atau hubungan antar independent variable dengan nilai tolerance $\geq 0,01$ atau sama dengan nilai VIF $\leq 10$ [33]. Hasil uji multikolinearitas pada penelitian ini menunjukkan bahwa nilai tolerance kualitas website sebesar $0,502 \geq 0,01$, impulsive personality trait sebesar $0,463 \geq 0,01$ dan kelompok referensi sebesar $0,460 \geq 0,01$. Begitupun dengan nilai VIF kualitas website sebesar 1,991 $\leq 10$, impulsive personality trait sebesar $2,159 \leq 10$, dan kelompok referensi sebesar 2,175 $\leq 10$. Maka dapat disimpulkan tidak terjadi multikolinearitas pada penelitian ini.
Dalam penelitian ini menunjukkan tidak ada gejala heteroskedasitas sehingga penelitian memiliki persamaan variance residual dalam satu periode pengamatan dengan periode pengamatan lain. Berdasarkan tiga uji asumsi klasik yang dilakukan, penelitian ini telah memenuhi uji normalitas, uji multikolinearitas dan uji heteroskedasitas. Sehingga data dalam penelitian ini layak dilanjutkan ke analisis data untuk pengujian hipotesis.

Kemudian hasil uji kelayakan model menunjukkan bahwa nilai $\mathrm{R}$ sebesar 0,748 . Hal ini mengartikan bahwa terjadi hubungan yang kuat antara variabel kualitas website, impulsive personality trait, dan kelompok referensi terhadap pembelian impulsif. Sedangkan nilai adjusted $R$ square sebesar 0,552 atau $55,2 \%$. Hal ini menunjukkan persentase sumbangan pengaruh variabel dependen kualitas website, impulsive personality trait, dan kelompok referensi terhadap variabel dependen pembelian impulsif pada Tokopedia.com adalah sebesar 55,2\% sedangkan sisanya $44,8 \%$ dipengaruhi variabel lain.

\section{Uji Hipotesis}

Pengujian hipotesis menggunakan alat uji statistik untuk mengetahui pengaruh variabel bebas terhadap variabel terikat dengan melihat hasil nilai signifikansi. Apabila signifikansi $<0,05$ maka variabel bebas berpengaruh signifikan terhadap variabel terikat, dan sebaliknya jika nilai signifikansi $>0,05$ maka variabel bebas dikatakan tidak mempengaruhi variabel terikat. Hasil uji hipotesis dapat dilihat pada tabel 3.

Tabel 3. Hasil Uji Hipotesis

\begin{tabular}{lc}
\hline & Sig \\
\hline Kualitas website & 0,043 \\
\hline Impulsive personality trait & 0,000 \\
\hline Kelompok referensi & 0,001 \\
\hline
\end{tabular}

Sumber: Output SPSS 22

Berdasarkan hasil analisis pada tabel 3, pengaruh kualitas website terhadap pembelian impulsif diperoleh nilai signifikansi sebesar 0,043 < 0,05 maka kualitas website dinyatakan berpengaruh signifikan terhadap pembelian impulsif. Sedangkan pengaruh impulsive personality trait terhadap pembelian impulsif diperoleh nilai signifikansi sebesar 0,000 < 0,05 yang artinya impulsive personality trait berpengaruh signifikan terhadap pembelian impulsif. Selanjutnya pengaruh kelompok referensi terhadap pembelian impulsif, diperoleh nilai signifikansi sebesar $0,001<0,05$ maka kelompok referensi berpengaruh signifikan terhadap pembelian impulsif. 


\section{Hasil Analisis Regresi Linear Berganda}

Analisis regresi linear berganda merupakan analisis yang digunakan untuk menguji perubahan variabel dependen terhadap perubahan variabel independen [33]. Dalam penelitian ini teknik analisis data digunakan untuk mengetahui pengaruh kualitas website $\left(\mathrm{X}_{1}\right)$, impulsive personality trait $\left(\mathrm{X}_{2}\right)$, dan kelompok referensi $\left(\mathrm{X}_{3}\right)$ terhadap pembelian impulsif (Y).

Model atau persamaan regresi linear berganda sebagai berikut:

$\mathrm{Y}=1,377+0,103 \mathrm{X} 1+0,413 \mathrm{X} 2+0,190 \mathrm{X} 3$

Hasil uji regresi linier berganda dapat dilihat pada tabel 4 sebagai berikut:

Tabel 4. Hasil Analisis Regresi Linear Berganda Sumber: Output SPSS 22

\begin{tabular}{|c|c|c|c|c|c|}
\hline \multirow[b]{2}{*}{ Model } & \multicolumn{2}{|c|}{$\begin{array}{c}\text { Unstandardi } \\
\text { zed } \\
\text { Coefficients } \\
\end{array}$} & \multirow{2}{*}{$\begin{array}{c}\begin{array}{c}\text { Standardized } \\
\text { Coefficients }\end{array} \\
\text { Beta }\end{array}$} & \multirow[b]{2}{*}{$\mathbf{t}$} & \multirow[b]{2}{*}{ Sig } \\
\hline & B & $\begin{array}{c}\text { Std. } \\
\text { Error }\end{array}$ & & & \\
\hline Const & 1,377 &, 858 & & 1,605 &, 110 \\
\hline $\begin{array}{l}\text { Kualitas } \\
\text { Website }\end{array}$ & ,103 &, 050 & ,137 & 2,041 & ,043 \\
\hline $\begin{array}{l}\text { Impulsive } \\
\text { Personality } \\
\text { Trait }\end{array}$ & ,413 & ,062 & ,463 & 6,634 &, 000 \\
\hline $\begin{array}{l}\text { Kelompok } \\
\text { Referensi }\end{array}$ & ,190 & ,057 & ,234 & 3,351 & ,001 \\
\hline
\end{tabular}

Berdasarkan hasil analisis pada tabel 4, maka disimpulkan sebagai berikut:

1. Nilai konstanta sebesar 1,377 menunjukkan bahwa kualitas website, impulsive personality trait, dan kelompok referensi sama dengan 0 maka besarnya pembelian impulsif sebesar 1,377 . Nilai positif konstanta menunjukkan bahwa meskipun tidak ada kualitas website, impulsive personality trait dan kelompok referensi maka pembelian impulsif tetap terjadi dengan nilai sebesar 1,377.

2. Koefisien regresi X1 sebesar 0,103 menyatakan bahwa semakin baik kualitas website maka akan meningkatkan pembelian impulsif sebesar 10,3\%.

3. Koefisien regresi X2 sebesar 0,413 menyatakan bahwa semakin tinggi impulsive personality trait maka akan meningkatkan pembelian impulsif sebesar $41,3 \%$.

4. Koefisien regresi X3 sebesar 0,190 menyatakan bahwa semakin baik kelompok referensi maka akan meningkatkan pembelian impulsif sebesar $19 \%$.

\section{Pembahasan}

\section{Pengaruh Kualitas Website (X1) terhadap Pembelian Impulsif (Y)}

Berdasarkan uji yang telah dilakukan, Maka dapat disimpulkan $\mathrm{H} 0$ ditolak dan $\mathrm{H} 1$ diterima, sehingga dapat dijelaskan bahwa variabel kualitas website (X1) memiliki pengaruh secara signifikan terhadap pembelian impulsif (Y). Hal ini mengartikan jika kualitas website mengalami peningkatan, maka akan meningkatkan pembelian impulsif. Kualitas website merupakan hal utama yang menjadi pertimbangan konsumen pada saat melakukan belanja secara online. Apabila e-commerce Tokopedia.com meningkatkan kualitas websitenya maka hal tersebut akan membentuk kenyamanan pengguna sehingga mampu meningkatkan pembelian impulsif. Hasil dari penelitian ini mendukung pernyataan beberapa ahli bahwa kualitas website berpengaruh signifikan terhadap pembelian impulsif [6], [7].

Jika dikaitkan dengan karakteristik responden, mayoritas responden pada penelitian ini berjenis kelamin perempuan sebesar 67,5\%, dengan usia 18-25 tahun dan berpendapatan per bulan kurang dari Rp 1.000.000. Hali ini dapat terjadi karena usia 18-25 tahun merupakan usia produktif seseorang untuk mencari tahu dan mencoba hal-hal baru termasuk mengikuti tren berbelanja online. Maka kualitas website menjadi hal yang dipertimbangkan konsumen untuk menunjang kenyamanan mereka saat berbelanja. Selain itu berbelanja secara online juga dianggap efisien dan lebih terjangkau.

\section{Pengaruh Impulsive Personality Trait (X2) terhadap Pembelian Impulsif (Y)}

Berdasarkan uji yang telah dilakukan, maka dapat disimpulkan $\mathrm{H} 0$ ditolak dan $\mathrm{H} 2$ diterima, sehingga dapat dijelaskan bahwa variabel impulsive personality trait (X2) memiliki pengaruh secara signifikan terhadap pembelian impulsif $(\mathrm{Y})$. Hal ini mengartikan bahwa semakin tinggi sifat impulsif seseorang maka akan berpengaruh terhadap perilaku pembelian impulsifnya. Impulsive personality trait merupakan sifat konsumen yang dapat memicu terjadinya pembelian impulsif berdasarkan dorongan dari dalam diri konsumen. Hasil dari penelitian ini mendukung pernyataan beberapa ahli bahwa Impulsive personality trait berpengaruh signifikan terhadap pembelian impulsif [9], [18].

Jika dikaitkan dengan karakteristik responden, responden pada penelitian ini merupakan perempuan sebesar $67,5 \%$, dengan usia 18-25 tahun yang telah melakukan pembelian impulsif di Tokopedia.com. Hal 
ini dapat terjadi karena perempuan pada usia tersebut seringkali tidak melakukan perencanaan ketika mengunjungi situs belanja online seperti Tokopedia.com, sehingga pada saat melihat berbagai macam produk bagus dengan penawaran yang menarik, sifat impulsif pada diri konsumen akan meningkat dan dapat mengarahkan pada pembelian impulsif.

\section{Pengaruh Kelompok Referensi (X3) terhadap Pembelian Impulsif (Y)}

Berdasarkan uji yang telah dilakukan, maka dapat disimpulkan $\mathrm{H} 0$ ditolak dan $\mathrm{H} 3$ diterima, sehingga dapat dijelaskan bahwa variabel kelompok referensi (X3) memiliki pengaruh secara signifikan terhadap pembelian impulsif (Y). Konsumen cenderung akan lebih mudah melakukan transaksi ketika sudah mendapatkan informasi dari orang disekitarnya sehingga dapat mendorong pembelian impulsif Hasil dari penelitian ini mendukung pernyataan beberapa ahli bahwa kelompok referensi berpengaruh signifikan terhadap pembelian impulsif [25], [24], [34].

Jika dikaitkan dengan karakteristik responden, mayoritas responden pada penelitian ini merupakan perempuan sebesar $67,5 \%$, dengan usia 18-25 tahun yang berstatus sebagai mahasiswa. Mahasiswa pada usia tersebut cenderung suka membentuk kelompok pertemanan untuk mencari informasi, karena mereka memiliki banyak waktu untuk bertemu dan berinteraksi satu sama lain sehingga lebih rentan untuk terpengaruh, termasuk perilaku dalam berbelanja. mereka akan mengikuti kelompok referensinya yang dapat mendorong untuk melakukan pembelian impulsive.

\section{A. KESIMPULAN}

\section{KESIMPULAN DAN SARAN}

Berdasarkan hasil analisis dan pembahasan pada penelitian ini maka disimpulkan bahwa terdapat pengaruh yang signifikan kualitas website terhadap pembelian impulsif pada e-commerce Tokopedia.com, terdapat pengaruh yang signifikan impulsive personality trait terhadap pembelian impulsif pada $e$ commerce Tokopedia.com, dan terdapat pengaruh yang signifikan kelompok referensi terhadap pembelian impulsif pada e-commerce Tokopedia.com. Hal ini mengisyaratkan bahwa e-commerce yang memiliki kualitas website yang baik, sifat impulsif dari dalam diri konsumen yang tinggi, dan kelompok referensi disekitar konsumen yang nyaman akan meningkatkan pembelian impulsif pada e-commerce. Kelemahan penelitian ini yaitu tidak menggunakan variabel moderasi seperti Shopping enjoyment sebagai penguat kualitas website sebelum melakukan pembelian impulsif. Selain itu cara pengumpulan data pada penelitian ini hanya dilakukan secara online.

\section{B. SARAN}

Bagi penelitian selanjutnya, diharapkan peneliti mampu menambahkan variabel moderasi sebagai penguat variabel dan mengumpulkan data secara online dan offline agar menghindari kecurangan yang mungkin terjadi, seperti responden melakukan pengisian lebih dari 1 kali. Selain itu peneliti selanjutnya diharapkan untuk menggunakan variabel lain yang berhubungan dengan pembelian impulsif di luar variabel yang digunakan dalam penelitian ini karena kontribusi yang diberikan hanya sebesar 55,2\% sedangkan sisanya 44,8\% dijelaskan oleh variabel lain. Variabel lain yang dapat digunakan dapat berasal dari dalam maupun luar individu. Dari dalam individu seperti shopping lifestyle atau hedonic shopping motivation. Kemudian dapat juga berasal dari luar individu yaitu pengaruh lingkungan pada situasi pembelian seperti situational factor dengan variabelnya yaitu money availability, time availability, dan task definition. Selain itu peneliti lain sebaiknya menggunakan objek penelitian e-commerce besar lainnya seperti Shopee.com atau Lazada.co.id.

\section{REFERENSI}

[1] Hari Widowati, "Indonesia Jadi Negara dengan Pertumbuhan E-Commerce Tercepat di Dunia," 25 April, 2019. [Online]. Available: https://databoks.katadata.co.id/datapublish/201 9/04/25/indonesia-jadi-negara-denganpertumbuhan-e-commerce-tercepat-di-dunia.

[2] D. A. Harahap, "Perilaku Belanja Online Di Indonesia: Studi Kasus," JRMSI - J. Ris. Manaj. Sains Indones., vol. 9, no. 2, pp. $193-$ 213, 2018.

[3] M. Saad and M. Metawie, "Store Environment, Personality Factors and Impulse Buying Behavior in Egypt: The Mediating Roles of Shop Enjoyment and Impulse Buying Tendencies," J. Bus. Manag. Sci., vol. 3, no. 2, pp. 69-77, 2015.

[4] C. W. Utami, Manajemen Ritel Strategi Dan Implementasi Ritel Modern. Jakarta Selatan: Salemba Empat, 2012.

[5] G. Mohan, B. Sivakumaran, and P. Sharma, "Store environment's impact on variety seeking behavior," J. Retail. Consum. Serv., vol. 19, no. 4, pp. 419-428, 2012. 
[6] Akram, "Asia Pacific Journal of Marketing and Logistics Article information," https Pacific J. Mark. Logist., vol. 30, pp. 725-748, 2018.

[7] S. Godara and V. K. Bishnoi, "A study on influence of website quality on online impulse buying behavior of Indian consumer," $J$. Gujarat Res. Soc., vol. 21, no. 10, p. 15, 2019.

[8] S. T. Mathai and R. Haridas, "an Empirical Study on the Impulsive Buying Behavior in Women and Factors Affecting Such Behavior," Procedia - Soc. Behav. Sci., vol. 5, no. 4, pp. 69-76, 2015.

[9] S. Hussain and D. A. Siddiqui, "The Influence of Impulsive Personality Traits and Store Environment on Impulse Buying of Consumer in Karachi," Int. J. Bus. Adm., vol. 10, no. 3, p. 50, 2019.

[10] U. Sumarwan, Manajemen ... Perilaku Konsumen Teori Dan Penerapannya Dalam. Pemasaran. Bogor: Ghalia Indonesia, 2011.

[11] A. Nurul, "Analisis Faktor-Faktor Pembelian Impulsif pada Shopee," vol. 6, no. 3, pp. 55105516, 2019.

[12] N. Maarif, "Tokopedia Jadi Tempat Bekerja Terbaik Versi HR Asia Award 2020," Rabu 07 Oktober, 2020. [Online]. Available: https://inet.detik.com/cyberlife/d-

5203610/tokopedia-jadi-tempat-bekerjaterbaik-versi-hr-asia-award-2020.

[13] U. D. Arni, "Tokopedia Vs Shopee," 04 Juli, 2018. [Online]. Available: https://garudacyber.co.id/artikel/794tokopedia-vs-shopee.

[14] Iprice.com, "The Map o E-Commerce in Indonesia," 09 Februari, 2021. [Online]. Available:

https://iprice.co.id/insights/mapofecommerce/e $\mathrm{n} /$.

[15] D. K. Dey and A. Srivastava, "Impulse buying intentions of young consumers from a hedonic shopping perspective," J. Indian Bus. Res., vol. 9, no. 4, pp. 266-282, 2017.

[16] H. Jundrio and K. Keni, "Pengaruh Website Quality, Website Reputation Dan Perceived Risk Terhadap Purchase Intention Pada Perusahahaan E-Commerce," J. Muara Ilmu Ekon. dan Bisnis, vol. 4, no. 2, p. 229, 2020.

[17] Roberts, et al., "I need my smartphone: A hierarchical model of personality and cellphone addiction," Pers. Individ. Dif., vol. 79, pp. 13-19, 2015.

[18] et al. Vazifehdoost, "Evaluation of the influence of fashion involvement, personality characteristics, tendency to hedonic consumption and store environment on fashionoriented impulse buying," Mediterr. J. Soc. Sci., vol. 5, no. 16, pp. 223-231, 2014.

[19] T. H. Dharmmesta, B.S. \& Handoko, Manajemen Pemasaran: Analisis Perilaku Konsumen., Cetakan ke. Yogyakarta: BPFE, 2008.

[20] J. D. Wells, "Online Impulse Buying: Understanding the Interplay between Consumer Impulsiveness and Website Quality," J. Assoc. Inf. Syst., vol. 12, no. 1, pp. 32-56, 2011.

[21] R. S. Hayu, Surachman, A. Rofiq, and M. Rahayu, "The effect of website quality and government regulations on online impulse buying behavior," Manag. Sci. Lett., vol. 10, no. 5, pp. 961-968, 2020.

[22] A. T. Wiranata and A. Hananto, "Do Website Quality, Fashion Consciousness, and Sales Promotion Increase Impulse Buying Behavior of E-Commerce Buyers?," Indones. J. Bus. Entrep., vol. 6, no. 1, pp. 74-85, 2020.

[23] Parsad, "Impact of Impulsive Personality Traits and Store Environment on Impulse Buying Behavior," Eur. J. Mark., pp. 1-24, 2017.

[24] L. U. Pei-Hsun and S. U. Ching-Shu, "A study of the factors influencing customers' impulse buying behavior in restaurants," Adv. Hosp. Tour. Res., vol. 6, no. 1, pp. 47-67, 2018.

[25] J. Rochmulysni, Widji, “(2017) Hedonic Value As Mediating Affects on Store Atmosphere and References Groups on Impulse Buying At Departemen Stores.Pdf," vol. 15, no. 2. pp. 3547, 2017.

[26] S. H. DM Danuza, "Hubungan Intensitas Mengakses Online Shop dan Tingkat Kepercayaan Rekomendasi Peer Group dengan Pembelian Impulsif Secara Online," 2018.

[27] N. K. Malhotra, Riset Pemasaran: Pendekatan Terapan, Edisi Keem. Jakarta: PT Indeks Kelompok Gramedia, 2017.

[28] M. Husnain, B. Rehman, F. Syed, and M. W. Akhtar, "Personal and In-store Factors Influencing Impulse Buying Behavior among Generation Y Consumers of Small Cities," Bus. Perspect. Res., vol. 7, no. 1, pp. 92-107, 2019.

[29] T. Harnoto, Y. Budi, and R. Silintowe, "Keputusan Pembelian Smartphone Oleh Mahasiswa: Kelompok Acuan Atau Gaya Hidup," J. Ilmu Komun., vol. 30, no. 2, pp. 181- 
197, 2018.

[30] H. W. Prakoso and S. S. Iriani, "Pengaruh Kualitas Produk dan Kelompok Acuan terhadap Keputusan Pembelian Sepeda Motor Suzuki Satria F150," J. Res. Econ. Manag. (Jurnal Ris. Ekon. dan Manaj., vol. 15, no. 2, pp. 262-279, 2015.

[31] I. Dananjaya and G. Suparna, "Hedonic Consumption Tendency Dan Impulse Buying Pelanggan Produk Fashion Di Mall Bali Galeria," E-Jurnal Manaj. Univ. Udayana, vol. 5, no. 4, p. 254937, 2016.

[32] Sugiyono, Metode Penelitian Pendidikan (Pendekatan Kuantitatif,. Kualitatif dan R\&D). Bandung: CV. Alfabeta, 2015.

[33] Ghozali, Aplikasi Analisis Multivariete Dengan Program IBM SPSS. Semarang: Universitas Diponegoro, 2016.

[34] Renn Risqiani, "Antecedents and consequences of Impluse Buying Behavior," Bus. Entrep. Rev. Entrep. Rev., vol. 15, no. 1, pp. 1-20, 2015. 